\title{
Effects of nutrients, planktivorous fish and water column depth on components of the microbial food web
}

\author{
A. Tzaras ${ }^{1, *}$, F. R. Pick ${ }^{1, * *}$, A. Mazumder ${ }^{2}$, D. R. S. Lean ${ }^{3, * * *}$ \\ ${ }^{1}$ Ottawa-Carleton Institute of Biology, University of Ottawa, Ottawa, Ontario K1N6N5, Canada \\ ${ }^{2}$ Département de Sciences Biologiques, Université de Montréal, Montréal, Quebec H3C 3J7, Canada \\ ${ }^{3}$ National Water Research Insitute, Canada Center for Inland Waters, PO Box 5050, Burlington, Ontario L7R 4A6, Canada
}

\begin{abstract}
An experimental study was conducted using large enclosures to examine the effects of nutrients, presence of planktivorous fish, and depth of the water column on the components of the microbial food web. Enclosures ( $8 \mathrm{~m}$ in diameter) were installed, open to the sediments, at both 3.5 and $11 \mathrm{~m}$ depths in Lac Croche, a small oligotrophic lake on the Canadian Shield. The abundance of protozoans, including obligate heterotrophic flagellates (HNAN) and potentially mixotrophic flagellates (MIXO), was examined in relation to the abundance of their prey, both heterotrophic bacteria (HBAC) and picocyanobacteria (PPICO). HBAC levels increased over the summer and were significantly higher in the nutrient enriched enclosures. While HBAC did not respond in a consistent manner to the presence of fish, the effect of nutrients was greater when fish were present. HBAC levels did not differ significantly between the shallow and deep enclosures. In contrast, PPICO were significantly affected by all 3 independent variables ; nutrients had a strong overall negative effect on abundance and the presence of fish tended to increase their abundance particularly in the shallow enclosures. Similarly, nutrient additions resulted in significantly lower HNAN levels, but neither the presence of fish nor depth of the water column significantly affected HNAN. However, the lowest average HNAN concentrations were in the deep nutrient enriched enclosures without fish, where the highest populations of Daphnia middendorffiana developed. MXXO were most abundant early in the season (exceeding HNAN) but declined significantly by mid-summer and were generally not as abundant as HNAN. MIXO levels were significantly lower in the nutrient enriched enclosures. Depth of the water column had a significant effect on MIXO, but MIXO levels were not affected in a consistent manner by the presence of fish. Experimental results did not demonstrate that increases in nutrient levels would lead to increases in HNAN as current empirical models imply. There was no increase in HNAN abundance related to increased bacterial abundance.
\end{abstract}

KEY WORDS: Microbial food web · Picoplankton - Nutrients · Zooplankton - Top-down control

\section{INTRODUCTION}

During the past decade, the ecological role of protozoa in aquatic systems has become the focus of exten-

Present addresses:

- New York City Dept. of Environmental Protection, Bureau of Water Quality, Supply and Protection, Corona, New York 11368-5107, USA

-.Ottawa-Carleton Institute of Biology, University of Ottawa, Ottawa, Ontario K1N 6N5, Canada

- Addressee for correspondence.

E-mail: frpick@science.uottawa.ca sive research (Fenchel 1987, Porter et al. 1988). Heterotrophic nanoflagellates (HNAN) are generally the most abundant protozoa in the euphotic zone of aquatic systems and are now considered an important component of pelagic food webs (e.g. Azam et al. 1983, Sherr \& Sherr 1984). Several studies have recognized these protozoa as the principal consumers of bacteria and picoplankton. They control bacterial populations through grazing and convert bacterial production into larger particles, which can then be utilized as food by larger protozoans and metazoans (e.g. Sherr \& Sherr 1984, Andersen \& Fenchel 1985, Sanders et al. 1989). 
Furthermore, HNAN play a key role in regulating nutrient flow through the microbial loop of aquatic systems. Substantial amounts of organic carbon, nitrogen, and phosphorus contained in their prey (picoplankton) are released into the environment as regenerated minerals (e.g. Goldman \& Caron 1985)

Several factors potentially regulate the abundance of HNAN. The abundance of prey may be the most important factor regulating HNAN seasonal levels (Fenchel 1982). A close coupling between HNAN and bacteria has been observed in several systems (e.g. Rassoulzadegan \& Sheldon 1986) although not all (e.g. Pick \& Hamilton 1994, Šimek et al. 1997). In turn, bacterial abundance or productivity has been correlated with algal biomass or primary production over a wide range of marine and freshwater systems (Bird \& Kalff 1984, Cole et al. 1988). Berninger et al. (1991) described a significant correlation between bacterial abundance and HNAN abundance over a wide range of freshwater systems, suggesting that system productivity may be the most significant factor regulating HNAN. However, in temperate lakes of Eastern Canada, HNAN abundance was not correlated with bacterial abundance although total phosphorus explained some of the variation observed between lakes (Tzaras \& Pick 1994). A more extensive data analysis for a variety of aquatic systems by Gasol \& Vaqué (1993) suggests that the relationship between HNAN and bacteria is not strong in any system.

Secondly, the abundance of predators of HNAN may be equally important. Zooplankton and ciliates are both potential consumers of HNAN (Sanders \& Porter 1990). Seasonal declines in HNAN have been related to increases in zooplankton (e.g. Jürgens \& Güde 1991, Jürgens 1994, Sanders et al. 1994) or ciliates (Weisse et al. 1990). Experimental additions of Daphnia partially regulated HNAN abundance in lake container experiments (Pace \& Funke 1991). The correlation analyses of Gasol \& Vaqué (1993) indicate that cladoceran abundance can explain a large fraction of the total variation in HNAN observed in lakes.

Because zooplankton community structure can be altered by fish planktivory (e.g. McQueen et al. 1986), cascading effects on HNAN are possible. Riemann (1985) first showed experimentally that increases in planktivorous fish caused significant increases in HNAN. He attributed the increase to reduced predation from 2 large cladoceran species (Daphnia cucullata and $D$. galeata). Subsequent enclosure experiments confirmed these early results (Christoffersen et al. 1993). In comparing 2 lakes with contrasting food web structure, Vaque \& Pace (1992) found that the lake dominated by planktivorous fish (and containing small cladoceran species) also contained the highest flagellate abundance compared to the lake dominated by piscivorous fish and large Daphnia species. However, in experimental studies HNAN are not always affected by Daphnia additions (Pace \& Funke 1991). There is also evidence for efficient predation on HNAN by other metazoans such as rotifers and calanoid copepods (e.g. Sanders et al. 1994, Jürgens et al. 1996) and by ciliates (Arndt 1993).

A third factor is thermal stratification, which may have profound effects on the relative importance of the classical versus microbial food web (Cushing 1989). In stratified water small cells tend to dominate biomass and primary production and hence energy flow through the microbial loop is theoretically more significant (Porter et al. 1988, Kiørboe et al. 1990). In addition, the relative importance of top-down versus bottom-up control may be quite different in shallow versus deep lakes (Moss et al. 1994).

In general, experimental tests of the role of nutrient supply versus predation in regulating HNAN have been conducted in small containers or enclosures over short time periods (Riemann 1985, Pace \& Funke 1991). The effects of depth and thermal stratification on the microbial loop in general have yet to be tested. In the following study, large enclosures were used to investigate the response of the microbial food web to altered nutrients and overall food web structure. To address the relative significance of nutrient loading (bottomup) or predatory (top-down) control on flagellate abundance, we examined fertilized and unfertilized enclosures that either contained or excluded planktivorous fish. These manipulations were examined in stratified (deep) versus continuously mixed (shallow) systems within one lake. We examined the response of 4 main components of the microbial community: the heterotrophic bacteria (HBAC), the photosynthetic picoplankton (PPICO), which are also preyed on by protozoan flagellates (e.g. Nagata 1988, Fahnenstiel et al. 1991, Simek et al. 1997), the HNAN and potentially mixotrophic flagellates (MIXO), which can also be important consumers of picoplankton (e.g. Porter 1988. Sanders \& Porter 1988) as well as being frequently more abundant that HNAN in inland lakes (Pick \& Hamilton 1994).

\section{MATERIALS AND METHODS}

Study site. The enclosures were installed in Lac Croche ( $74^{\circ} 00^{\prime} \mathrm{N}, 45^{\circ} 59^{\prime} \mathrm{W}$ ), a small (4.82 ha), soft water, slightly dystrophic lake located at the Station de Biologie des Laurentides of the Université de Montréal, approximately $70 \mathrm{~km}$ north of Montréal on the Canadian Shield. The lake has a pH of 6.3 to 6.9 and dissolved organic carbon (DOC) levels range between 4 and $5 \mathrm{mg} \mathrm{l}^{-3}$ Spring total phosphorus levels average $10 \mathrm{\mu g} \mathrm{l}^{-1}$. 
The lake is dimictic, with a maximum depth of $11.5 \mathrm{~m}$ and a mean depth of $8.5 \mathrm{~m}$. The thermocline is at approximately $3 \mathrm{~m}$ in early June and the lake remains strongly stratified until vertical mixing in early October. The photic zone (depth of $1 \%$ of surface radiation) is approximately $7 \mathrm{~m}$ during the summer months. Epilimnion summer temperatures range between 20 and $25^{\circ} \mathrm{C}$ while hypolimnetic water temperatures range from 5 to $6^{\circ} \mathrm{C}$. Additional information concerning morphometric and physical characteristics of Lac Croche can be found in Lafond et al. (1990).

Enclosure and experimental design. Eight enclosures were installed in a shallow area of the lake at a depth of $3 \mathrm{~m}$, resulting in a total volume of $1.5 \times 10^{5} \mathrm{l}$ enclosure ${ }^{-1}$. The second set of 8 enclosures was installed in the deepest portion of the western basin of the lake at $11 \mathrm{~m}$ depth. The deep enclosures each had a total volume of $6.0 \times 10^{5} \mathrm{l}$. The volume of the epilimnion in the deep enclosures was approximately the same as the total volume of the shallow enclosures. The shallow enclosures were close to isothermal top to bottom while the deep enclosures were thermally stratified as of the middle of June, with a metalimnion extending from 3 to $5 \mathrm{~m}$ (Proulx et al. 1996).

The enclosures were constructed out of nylon reinforced polyethylene sheeting suspended in the water column by an $8^{\prime \prime}(20.3 \mathrm{~cm})$ polyurethane floating collar supported by a $2 " \times 4 "(5.1 \times 10.2 \mathrm{~cm})$ wood frame. A metal chain anchored the bottom of each enclosure in the sediment and prevented mixing of enclosure water with the surrounding lake water. Enclosures remained uncovered at both ends to allow for interaction with the underlying sediments and the atmosphere. A similar enclosure design was used in the experiments conducted at Lake St. George by McQueen et al. (1986) and Mazumder et al. (1988).

The 3 treatment variables under investigation were nutrients, presence of planktivorous fish and depth of the water column for a $3 \times 2$ factorial design. Each variable was manipulated at 2 levels: presence versus absence and shallow versus deep accordingly. The resulting treatment combinations were: (1) nutrient addition and fishless $(\mathrm{N}),(2)$ nutrient addition and fish present $(\mathrm{N}+\mathrm{F}$ ), (3) no nutrient addition and fishless (control) (C), and (4) no nutrient addition and fish present $(F)$. Each treatment combination had 2 replicates at each depth.

Treatment combinations requiring nutrients received nitrogen and phosphorus additions on a weekly basis at a $\mathrm{N}$ to $\mathrm{P}$ ratio of $13: 1$. Nitrogen was added as sodium nitrate $\left(\mathrm{NaNO}_{3}\right)$ at a level of 47.97 $\mathrm{mg} \mathrm{N} \mathrm{m} \mathrm{m}^{-2} \mathrm{~d}^{-1}$. Phosphorus was added in a liquid state as phosphoric acid $\left(\mathrm{H}_{3} \mathrm{PO}_{4}\right)$ at a level of $3.69 \mathrm{mg} \mathrm{P} \mathrm{m}^{-2}$ $\mathrm{d}^{-1}$. This fertilization rate represents a typical loading for a temperate eutrophic system (Mazumder et al.
1988). Epilimnetic total phosphorus levels in the enriched enclosures were about 4 times higher than in the non-enriched ones (34 to $39 \mu \mathrm{g} \mathrm{l}^{-1}$ vs $8 \mu \mathrm{g} \mathrm{l}^{-1}$ ), with the shallow and deep enclosures maintaining similar levels (Proulx et al. 1996). The resulting phytoplankton and zooplankton biomass along with estimates of primary production and heterotrophic bacterial production are summarized from various sources in Table 1.

Fishless enclosures were seined to remove any fish. Enclosures containing fish were stocked with a hybrid redbelly dace (Phoxinus eos $\times P$. neogaeus), a planktivore indigenous to Lac Croche. Approximately 160 to 170 minnows, 6 to $8 \mathrm{~cm}$ in length and weighing $2.6 \mathrm{~g}$ fish $^{-1}$, were added to give a final stocking of $5 \mathrm{~g} \mathrm{~m}^{-2}$. To ensure that fish remained in the designated enclosures, fish fences measuring $0.4 \mathrm{~m}$ high were erected to prevent fish from jumping in and out of the enclosures. In addition, fish traps were installed in the fishless enclosures to ensure that the fishless treatments remained fishless for the duration of the experiment. Only the deep fishless enclosures developed populations of large cladocerans: Daphnia middendorffiana attained average biomass levels of 139 and $147 \mu \mathrm{g} \mathrm{l}^{-1}$ in the deep $\mathrm{C}$ and $\mathrm{N}$ enclosures respectively (Table 1 , Proulx et al. 1996).

Sampling. Enclosures were sampled from June 19, 1991 (Julian day 173), until September 14, 1991 (Julian day 254), resulting in a total of 7 sampling

Table 1. Effects of nutrient additions and planktivorous fish on measures of productivity and plankton biomass in the shallow and deep enclosures. Values are summer averages (June 14 to August 29, n = 4 to 6) of integrated water column (shallow enclosures) or epilimnion (deep enclosures). PP: primary production as the average maximum photosynthetic rate, $\mu \mathrm{g} \mathrm{Cl}^{-1} \mathrm{~h}^{-1}$ (Perin et al. 1996). BP: bacterial production as the average thymidine assimilation rate, $\mathrm{pM} \mathrm{l}^{-1} \mathrm{~h}^{-1}$ (Howard 1994). Chl a: chlorophyll a as an estimate of algal biomass, $\mu \mathrm{g} \mathrm{l^{-1 }}$ ZB: zooplankton biomass, $\mu \mathrm{g} \mathrm{l}^{-1}$ (Proulx et al. 1996). DB: Daphnia biomass, $\mu \mathrm{g} \mathrm{l}^{-1}$ (Proulx et al. 1996). CA: ciliate abundance $\mathrm{l}^{-1}$ (Marchessault \& Mazumder 1997). Treatments: control, no nutrient addition and fishless; $F$, no nutrient addition and fish present; $N$, nutrient addition and fishless; $N+F$, nutrient and fish present. na: not applicable

\begin{tabular}{|lrrrrrr|}
\hline & PP & BP & Chl $a$ & ZB & DB & CA \\
\hline Shallow & & & & & & \\
Control & 14 & 7 & 2.5 & 1966 & 0.4 & na \\
F & 5 & 15 & 3.0 & 1004 & 1.0 & na \\
N & 174 & 48 & 8.5 & 2701 & 0.4 & na \\
N + F & 218 & 79 & 12.3 & 702 & 0.3 & na \\
Deep & & & & & & \\
Control & 7 & 4 & 2.4 & 591 & 139 & 1100 \\
F & 7 & 7 & 2.6 & 204 & 9 & 2000 \\
N & 82 & 23 & 7.1 & 1032 & 147 & 180 \\
N + F & 254 & 15 & 9.1 & 391 & 33 & 2000 \\
\hline
\end{tabular}


dates. Deep enclosures were not sampled during Week 1. Thus in the statistical analysis, data collected from Week 1 were not included.

The enclosures were fertilized on a weekly basis and sampling was conducted every other week. The time interval between the sampling dates and the enrichment dates was constant throughout the sampling period.

Epilimnetic water samples were collected using a plexiglass integrated tube sampler $(6.5 \mathrm{~cm}$ in diameter) over a 0 to $3 \mathrm{~m}$ depth. All samples were collected from the midpoint of each enclosure between 08:00 and $10: 30 \mathrm{~h}$. A total $16 \mathrm{l}$ of lake water were collected from each enclosure and stored in $20 \mathrm{l}$ opaque polyethylene containers which were pre-rinsed with surface whole lake water prior to each use. Sub-samples of whole lake water $(90 \mathrm{ml})$ were preserved immediately with $10 \mathrm{ml}$ of $10 \%$ glutaraldehyde buffered with $0.1 \mathrm{M}$ sodium cacodylate $(\mathrm{pH} 7)$. Samples were stored at $4^{\circ} \mathrm{C}$ in the dark for microbial slide preparations, which were made within $10 \mathrm{~d}$ of the collection date.

Enumeration methods. Preserved lake water samples were filtered through $0.2 \mu \mathrm{m}$ (for $\mathrm{HBAC}$ and PPICO) and $1.0 \mu \mathrm{m}$ (for nanoflagellate counts) Poretic filters prestained in a $0.2 \%$ solution of Irgalan black in $2 \%$ acetic acid. Direct counts of HBAC and HNAN were determined using DAPI (4'6 diamidino-2-phenylindole) staining and epifluorescence microscopy (Porter \& Feig 1980). PPICO counts were performed using green excitation (510 to $570 \mathrm{~nm}$ ) of phycocyanin as described in Pick \& Agbeti (1991). Non-phycoerythrin cyanobacteria dominated the picoplankton of Lac Croche and all the enclosures. Cell enumerations were conducted using a $100 \times$ oil immersion objective on a Zeiss Jenamed 2 epifluorescence microscope fitted with a $50 \mathrm{~W}$ HBO mercury lamp for a final magnification of $1200 \times$. A minimum of 500 bacteria cells was randomly counted per sample with the aid of an ocular grid.

Nanoflagellate counts were conducted under both blue and UV light. HNAN could be distinguished from phototrophic flagellates based on the absence or presence of photosynthetic pigments. HNAN fluoresced weakly and appeared green under blue light and whitish blue under UV. Conversely, non-heterotrophic flagellates fluoresced red to orange under blue excitation owing to the presence of chlorophyll $a$ and other photosynthetic accessory pigments and yellowish under UV. We considered the MIXO to include the pigmented chrysophytes and prymnesiophytes, which have been reported to consume bacteria (e.g. Porter 1988). In addition we included as potential mixotrophs pigmented cryptomonads, which may consume bacteria in laboratory cultures
(Porter 1988), although they are rarely reported to consume bacteria in nature (e.g. Bennett et al. 1990). Between 60 and 100 nanoflagellate cells were counted from each sample or until 45 random whole field views had been examined.

Statistical analyses. A repeated measures analysis of variance (RMANOVA) procedure was selected to evaluate the treatment effects, any temporal effects, as well as their interaction effects on the seasonal abundance of bacteria and nanoflagellates throughout the 4 mo study period (June to September).

The overall statistical model used was a Model I (fixed effects), 3-way RMANOVA. The data were analyzed using SAS software version 6.03 (SAS Institute Inc. 1989). The model was constructed using 3 class variables (nutrients, fish, and depth) arranged in 2 levels (presence vs absence and shallow vs deep), and a time trial factor consisting of 7 sampling dates for HBAC and 6 sampling dates for HNAN. The betweensubject effects are those due to the main treatment effects, that is, the addition of nutrients, presence of fish, and depth of the water column. The response of the dependent variable to the treatment effects is averaged over the entire sampling period. The error term is calculated from the number of enclosures.

RMANOVA accounts for the between-subject effects, then focuses the analysis on the treatment effects within each subject, that is, how the subject's response varies with time. Therefore, the tested null hypothesis is whether the response of the dependent variable to the different treatments is the same over time. Specifically, the within-subject analysis tests determine whether the slope of the best fit line through the observations plotted against time is similar for the different treatment combinations (Gurevitch \& Chester 1986). The error terms associated with the within-subject analyses are derived from the number of repeated measures.

Microbial abundances were all $\log$ transformed to satisfy the assumptions of normality and homogeneity of the residuals.

\section{RESULTS}

\section{Heterotrophic bacteria}

HBAC ranged from $3.1 \times 10^{5}$ to $5.7 \times 10^{6}$ cells $\mathrm{ml}^{-1}$ in the shallow enclosures throughout the sampling period (Fig. 1A). There was a general increase in HBAC throughout the summer months, with the highest cell abundance observed at the end of the sampling period (September 14, 1991). The nutrient enriched enclosures (alone or in combination with fish) supported greater HBAC abundance than was 

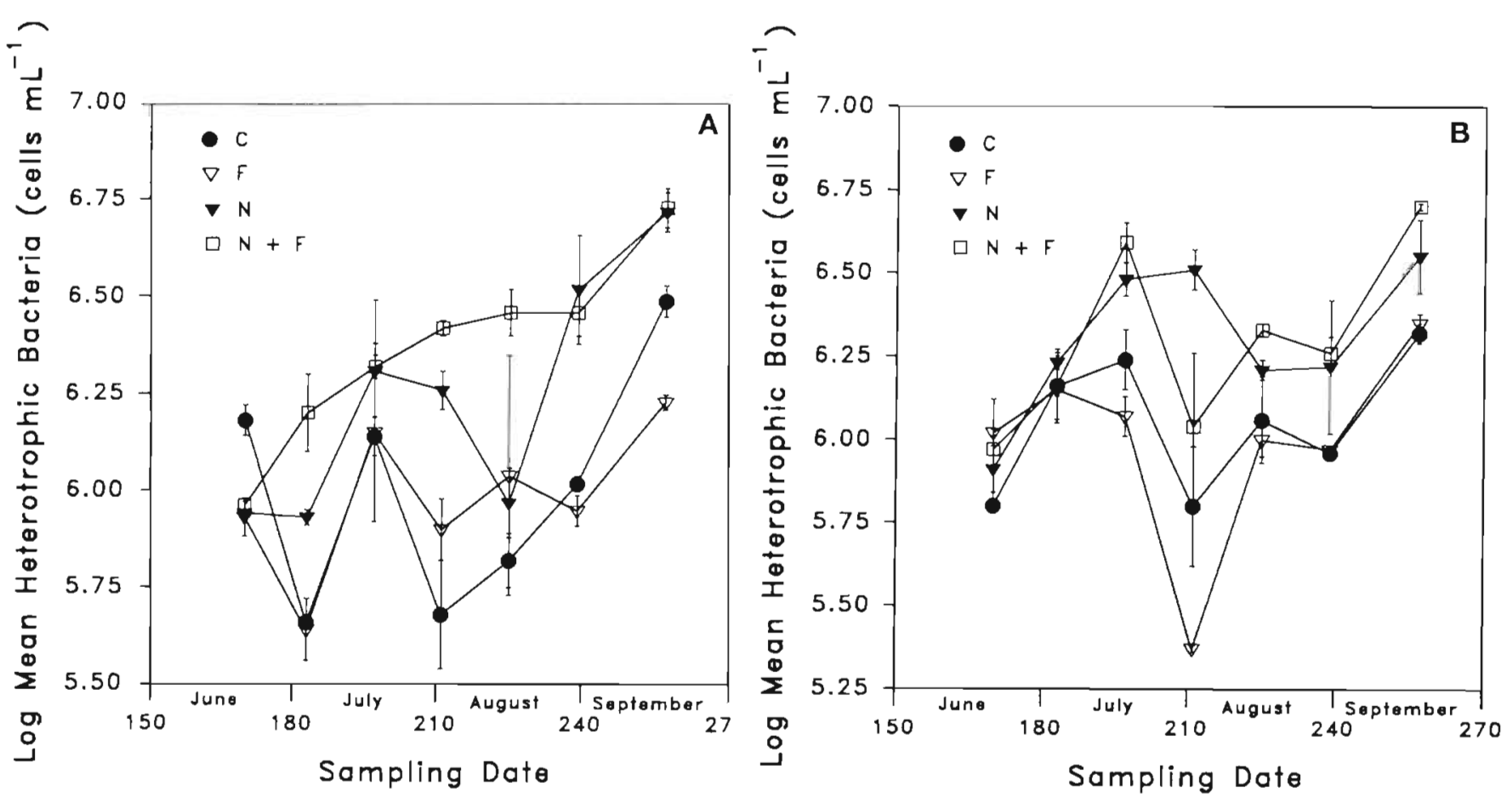

Fig. 1. Log transformed mean heterotrophic bacterial abundance in (A) the shallow enclosures ( $3 \mathrm{~m}$ ) and (B) the deep stratified enclosures $(11 \mathrm{~m})$ from June 19 to September 14, 1991. Error bars represent the standard deviation between replicate enclosures. Treatments were: $C$, control (no fish and no nutrient additions); $F$, planktivorous fish additions; $N$, nutrient additions; $N+F$, nutrient and fish additions. Numbers on the $x$-axis represent Julian days

observed in the control and fish only enclosures (Fig. 2).

HBAC trends in the deep enclosures were similar to those observed in the shallow enclosures (Fig. 1B). Mean cell abundance varied between $2.3 \times 10^{5}$ and $9.5 \times 10^{6}$ cells $\mathrm{ml}^{-1}$ and maximum abundance was observed at the end of the sampling period (September 14,1991 ). There was also a slight drop in HBAC abundance during mid-summer around July 30 , 1991. HBAC abundance in the nutrient enriched enclosures (with and without fish) was slightly higher than the control and fish only enclosures. Fish only enclosures had the lowest HBAC levels, but the levels were similar to those found in the control enclosures.

The overall effects of the 3 treatment variables, i.e. nutrient additions $(\mathrm{N})$, presence of planktivorous fish $(\mathrm{F})$, and depth of the water column (D), as well as their interaction effects on HBAC, are summarized in Table 2. Mean seasonal HBAC levels were significantly higher in the enclosures with added nutrients $(p=0.001$, Table 2, Fig. 2). While HBAC did not respond in a consistent manner to the presence of fish $(p=0.632)$, a significant nutrient and fish interaction effect was observed $(\mathrm{N} \times \mathrm{F} ; \mathrm{p}=0.031)$. $\mathrm{HBAC}$ levels were higher in the enriched enclosures containing fish in comparison to those without fish (Fig. 2). There was no significant difference in HBAC
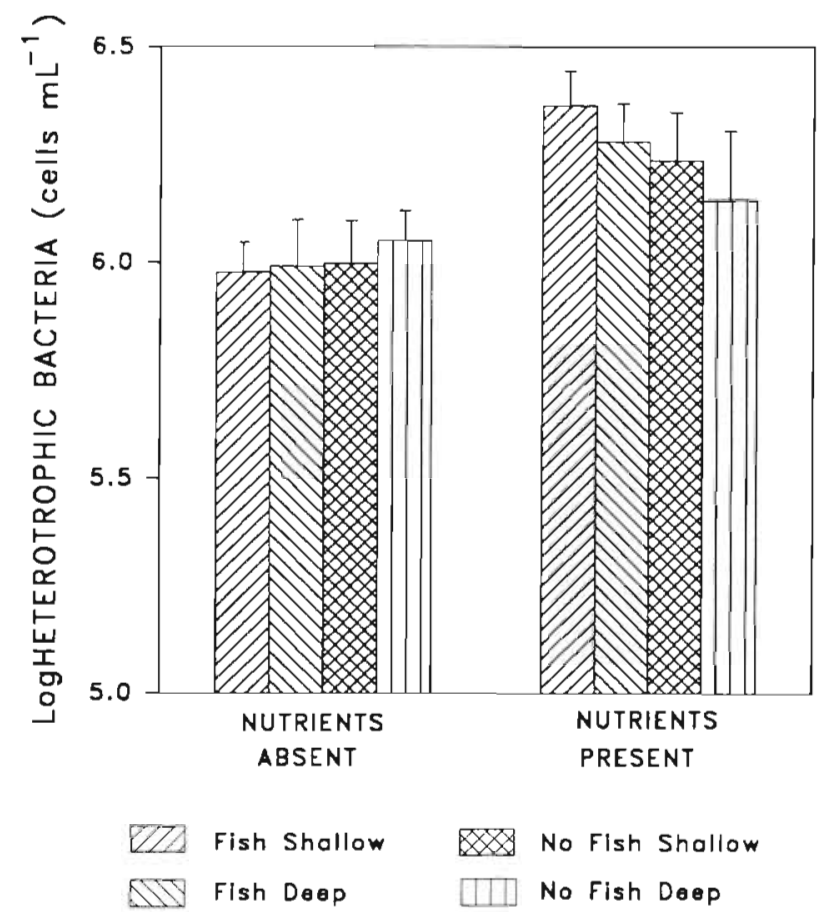

Fig. 2. Overall effects of the treatment variables on seasonal mean heterotrophic bacterial abundance. Treatments were: nutrient additions, presence of planktivorous fish and depth of the water column. Heterotrophic bacterial abundance has been log transformed. Seven sampling dates were included in the analyses. Bars represent standard errors 
Table 2. Between-subject effects. Summary of the repeated measures 3-way RMANOVA procedure examining the effects of nutrient additions $(N)$, presence of planktivorous fish $(F)$ and depth of the water column (D) on the log transformed heterotrophic bacterial abundance. ns: $\mathrm{p}>0.07$

\begin{tabular}{|lrrrrc|}
\hline Source & \multicolumn{1}{c}{ SS } & df & \multicolumn{1}{c}{ MS } & Fratio & p value \\
\hline $\mathrm{N}$ & 11.22 & 1 & 11.22 & 117.64 & 0.001 \\
$\mathrm{~F}$ & 0.02 & 1 & 0.02 & 0.25 & $\mathrm{~ns}$ \\
$\mathrm{~N} \times \mathrm{F}$ & 0.69 & 1 & 0.69 & 7.27 & 0.031 \\
$\mathrm{D}$ & 0.43 & 1 & 0.43 & 4.54 & $\mathrm{~ns}$ \\
$\mathrm{~N} \times \mathrm{D}$ & 0.06 & 1 & 0.06 & 0.62 & $\mathrm{~ns}$ \\
$\mathrm{~F} \times \mathrm{D}$ & 0.05 & 1 & 0.05 & 0.50 & $\mathrm{~ns}$ \\
$\mathrm{~N} \times \mathrm{F} \times \mathrm{D}$ & 0.01 & 1 & 0.01 & 0.09 & $\mathrm{~ns}$ \\
Error & 0.67 & 8 & 0.10 & & \\
\hline
\end{tabular}

abundance between the shallow and deep enclosures $(\mathrm{p}=0.071)$ and no interactions with the other treatment variables (Table 2 ).

Examination of the overall temporal effects (Table 3) indicated that HBAC abundance varied significantly throughout the sampling period ( $p<0.001$ ). The seasonal changes in HBAC abundance were influenced by nutrients $(p=0.001)$ but were not influenced by fish $(p=0.123)$. HBAC seasonal trends were significantly different in the shallow versus deep enclosures $(p=0.006)$ and furthermore depended on whether planktivorous fish were present $(\mathrm{W} \times \mathrm{F} \times \mathrm{D}$; $p<0.001)$ or nutrients were added $(W \times N \times D ; p=$ $0.010\}$.

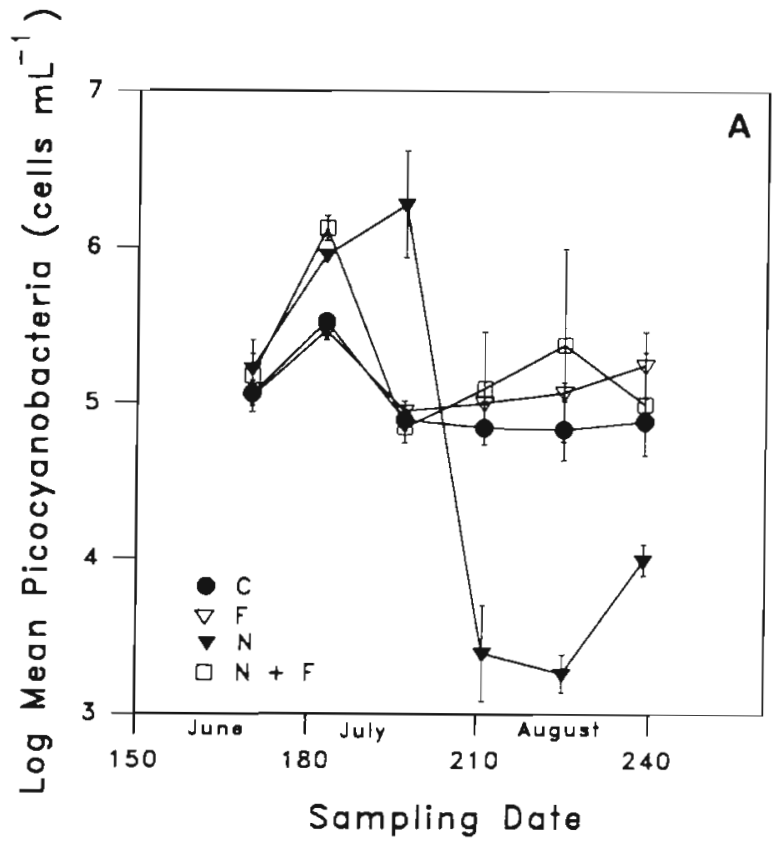

Table 3. Within-subject effects. Summary of the 3-way RMANOVA repeated procedure examining the response of log transformed heterotrophic bacterial abundance to nutrient additions (N), presence of planktivorous fish $(F)$ and depth of the water column (D) during the sampling period. W: sampling week. A total of 7 sampling dates were included in the analyses. ns: $p>0.14$

\begin{tabular}{lccc|}
\hline Source & df & Fratio & p value \\
\hline$W$ & 6 & 26.03 & $<0.001$ \\
$W \times N$ & 6 & 6.46 & $<0.001$ \\
$W \times F$ & 6 & 1.80 & $n s$ \\
$W \times N \times F$ & 6 & 1.01 & $n s$ \\
$W \times D$ & 6 & 3.56 & 0.006 \\
$W \times N \times D$ & 6 & 3.26 & 0.010 \\
$W \times F \times D$ & 6 & 5.99 & $<0.001$ \\
$W \times N \times F \times D$ & 6 & 0.07 & $n s$ \\
\hline
\end{tabular}

\section{Photosynthetic picoplankton}

In the shallow enclosures, PPICO levels were highest in the nutrient enriched enclosures (with or without fish) early in the sampling season (Fig. 3A). Cell abundance reached a maximum of $1.8 \times 10^{6}$ cells $\mathrm{ml}^{-1}$ in the nutrient only enclosures during mid-summer (July 16), but dropped 3 orders of magnitude to $2.5 \times 10^{3}$ cells $\mathrm{ml}^{-1}$ on the following sampling date (July 30). PPICO levels in the nutrient only enclosures remained considerably lower $\left(<10^{4}\right.$ cells $\left.\mathrm{ml}^{-1}\right)$ in comparison to the other enclosures for the remain-

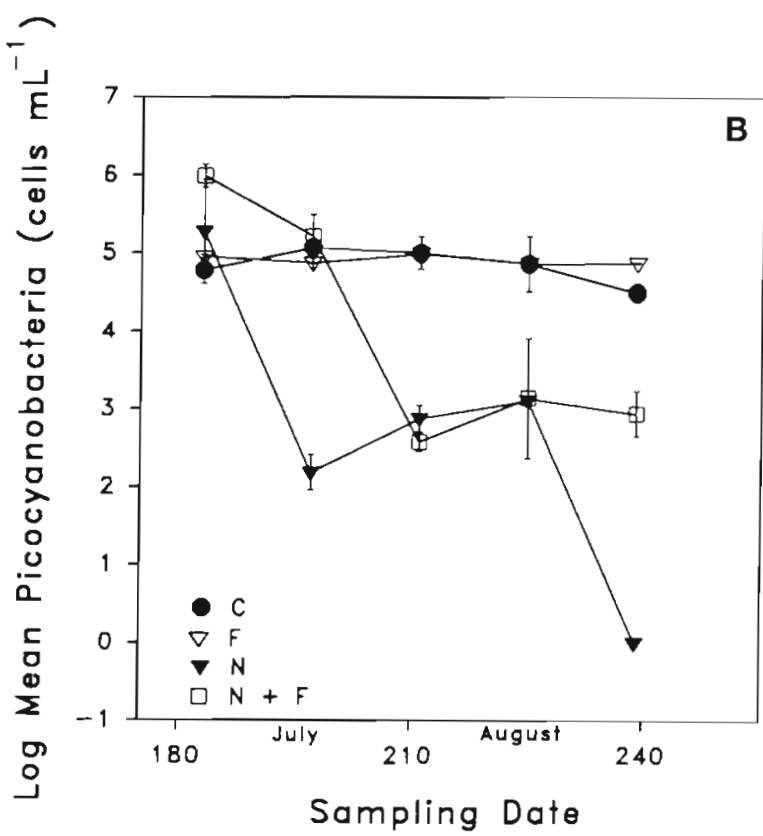

Fig. 3. Log transformed mean picocyanobacteria abundance in (A) the shallow enclosures ( $3 \mathrm{~m}$ ) and (B) the deep stratified enclosures (11. m) from June 19 to September. 14, 1991 Exror bars represent the standard deviation between replicate enclosures. Treatments were: $C$, control (no fish and no nutrient additions); $F$, planktivorous fish additions; $N$, nutrient additions: $N+F, n u t r i-$ ent and fish additions. Numbers on the $x$-axis represent Julian days 
Table 4. Between-subject effects. Summary of the 3-way RMANOVA examining effects of nutrient additions (N), presence of fish $(F)$, and depth of the water column (D) on log transformed picocyanobacteria abundance. ns: $p>0.33$

\begin{tabular}{|lrrrrc|}
\hline Source & SS & df & MS & Fratio & p value \\
\hline $\mathrm{N}$ & 63.05 & 1 & 63.05 & 78.58 & $<0.001$ \\
$\mathrm{~F}$ & 22.12 & 1 & 22.12 & 27.57 & $<0.001$ \\
$\mathrm{~N} \times \mathrm{F}$ & 12.27 & 1 & 12.27 & 15.29 & 0.005 \\
$\mathrm{D}$ & 62.54 & 1 & 62.54 & 77.96 & $<0.001$ \\
$\mathrm{~N} \times \mathrm{D}$ & 34.16 & 1 & 34.16 & 42.58 & $<0.001$ \\
$\mathrm{~F} \times \mathrm{D}$ & 0.37 & 1 & 0.37 & 0.46 & $\mathrm{~ns}$ \\
$\mathrm{~N} \times \mathrm{F} \times \mathrm{D}$ & 0.86 & 1 & 0.86 & 1.07 & $\mathrm{~ns}$ \\
Error & 6.42 & 8 & 0.80 & & \\
\hline
\end{tabular}

der of the sampling period. Enriched with fish $(\mathrm{N}+$ F) enclosures exhibited high PPICO levels in early July, but PPICO levels declined rapidly from $1.3 \times$ $10^{6}$ to $7.0 \times 10^{4}$ cells $\mathrm{ml}^{-1}$ during Week 3 and remained relatively constant around $2.0 \times 10^{5}$ cells $\mathrm{ml}^{-1}$ for the remainder of the summer months. PPICO levels in the control and fish only enclosures remained at $10^{5}$ cells $\mathrm{ml}^{-1}$ throughout the entire sampling period.

A greater range in PPICO abundance was observed in the deep enclosures in comparison to the shallow enclosures (Fig. 3B). Maximum cell abundance was observed in the $\mathrm{N}+\mathrm{F}$ enclosures during Week 2 of sampling (July 4). However, PPICO levels declined steadily and from the fourth sampling week PPICO abundance in the $\mathrm{N}+\mathrm{F}$ enclosures varied between $10^{2}$ to $10^{3}$ cells $\mathrm{ml}^{-1}$ for the remainder of the summer. Similarly, PPICO abundance in the nutrient only enclosures was initially higher than the control and fish only enclosures during early summer. PPICO abundance declined 3 orders of magnitude following the third sampling date. PPICO levels remained relatively stable at $10^{3}$ cells $\mathrm{ml}^{-1}$ until the end of the sampling period, when densities reached a minimum of $10^{2}$ cells $\mathrm{ml}^{-1}$. Control and fish only enclosures exhibited virtually identical trends throughout the sampling period (Fig. 3). In both cases, PPICO abundance did not deviate greatly from $10^{5}$ cells $\mathrm{ml}^{-1}$.

The RMANOVA between-subject analysis indicated that PPICO abundance was significantly affected by all 3 treatment variables (Table 4). Mean PPICO levels decreased with nutrient additions $(\mathrm{p}<$ 0.001 ); increased in the presence of fish $(p<0.001)$; and were more abundant in the shallow enclosures compared to the deep ( $p<0.001)$ (Fig. 4). The effect of nutrients was influenced by the presence of fish $(\mathrm{N} \times \mathrm{F} ; \mathrm{p}=0.005)$. Mean PPICO levels were lower in the nutrient enriched enclosures with no fish in comparison to those with fish (Fig. 4). Similariy, the effect of nutrients was influenced by the depth of the
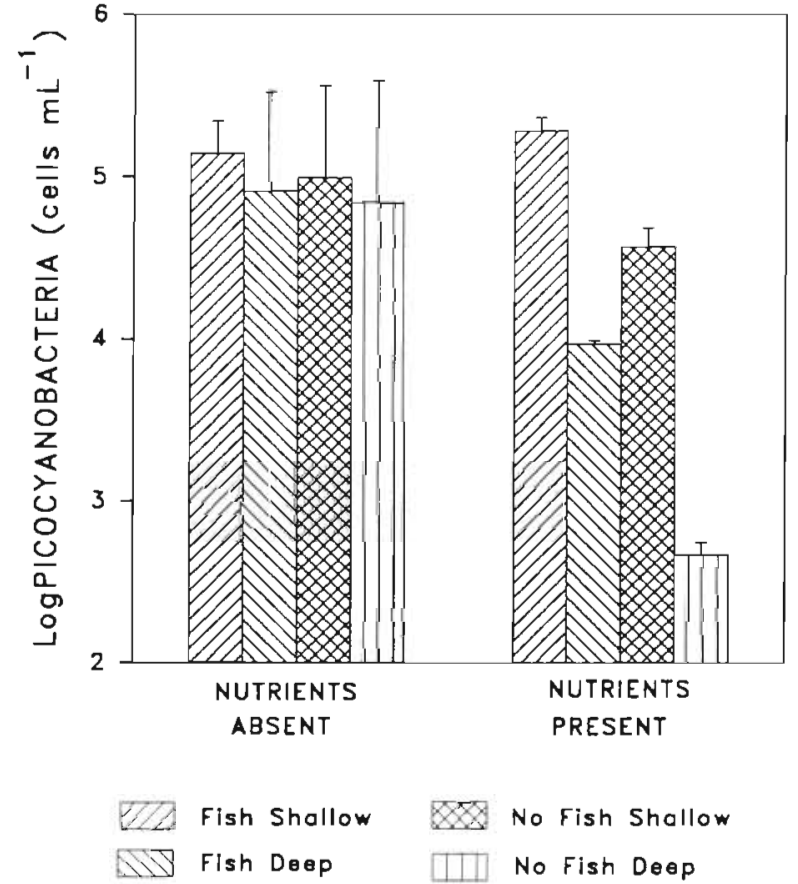

Fig. 4. Overall effects of the treatment variables on seasonal mean picocyanobacteria abundance. Treatments were: nutrient additions, presence of planktivorous fish and depth of the water column. Heterotrophic bacterial abundance has been log transformed. Seven sampling dates were included in the analyses. Bars represent standard errors

enclosure $(\mathrm{N} \times \mathrm{D} ; \mathrm{p}<0.001)$. PPICO levels were significantly lower in deep enclosures with added nutrients in comparison to the shallow ones with added nutrients (Fig. 4).

RMANOVA within-subject tests (Table 5) revealed that seasonal variation in PPICO levels depended on nutrient additions ( $p=0.003$ ) and the depth of the

Table 5. Within-subject effects. Summary of the 3-way RMANOVA procedure examining the response of log transformed picocyanobacteria abundance to the addition of nutrients $(N)$, presence of fish $(F)$, and depth of the water column (D) during the sampling period. W: sampling week. A total of 5 sampling dates were included in the analyses

\begin{tabular}{|lrrr|}
\hline Source & df & Fratio & p value \\
\hline $\mathrm{W}$ & 4 & 51.62 & $<0.001$ \\
$\mathrm{~W} \times \mathrm{N}$ & 4 & 20.41 & 0.003 \\
$\mathrm{~W} \times \mathrm{F}$ & 4 & 1.34 & 0.371 \\
$\mathrm{~W} \times \mathrm{N} \times \mathrm{F}$ & 4 & 1.11 & 0.444 \\
$\mathrm{~W} \times \mathrm{D}$ & 4 & 23.79 & 0.002 \\
$\mathrm{~W} \times \mathrm{N} \times \mathrm{D}$ & 4 & 47.49 & $<0.001$ \\
$\mathrm{~W} \times \mathrm{F} \times \mathrm{D}$ & 4 & 111.25 & $<0.001$ \\
$\mathrm{~W} \times \mathrm{N} \times \mathrm{F} \times \mathrm{D}$ & 4 & 134.34 & $<0.001$ \\
\end{tabular}



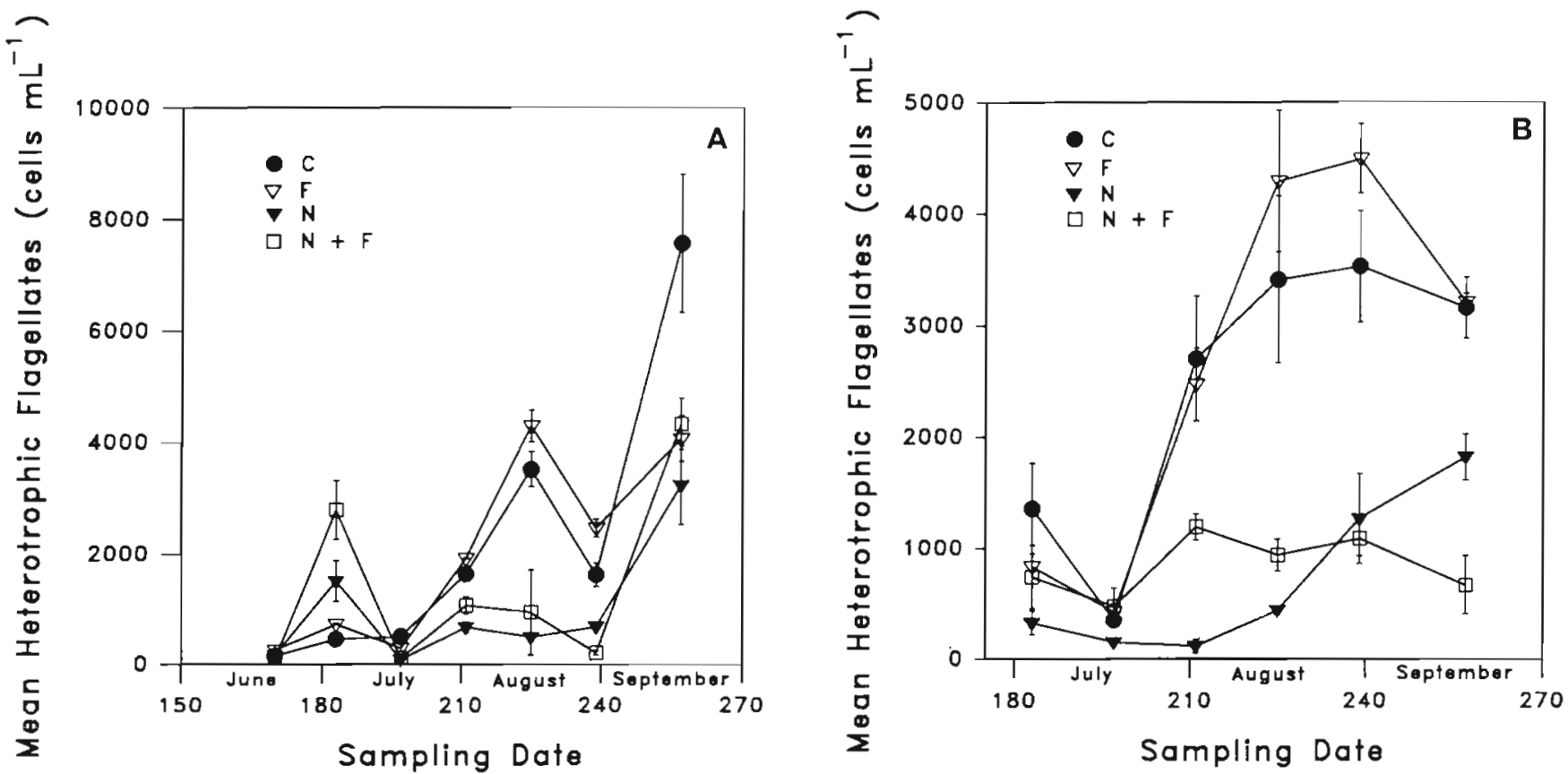

Fig. 5. Mean heterotrophic flagellate abundance in (A) the shallow enclosures $(3 \mathrm{~m})$ and $(B)$ the deep stratified enclosures $(11 \mathrm{~m})$ during the sampling period June 19 to September 14, 1991. Error bars represent the standard deviation between replicate enclosures. Treatments were: $\mathrm{C}$, control (no fish and no nutrient additions); $F$, planktivorous fish additions; $N$, nutrient additions; $N F$, nutrient and fish additions. Numbers on the $x$-axis represent Julian days

water column ( $\mathrm{p}=0.002)$ but did not depend consistently on the presence of fish $(p=0.371)$.

\section{Heterotrophic flagellates}

HNAN abundance ranged from 0.09 to $7.6 \times 10^{3}$ cells $\mathrm{ml}^{-1}$ in the shallow enclosures (Fig. 5A). Maximum HNAN was found in the control enclosures at the end of the sampling period on September 14. For most of the summer, excluding the second sampling week, HNAN abundance was highest in the control and fish only en-

Table 6. Between-subject effects. Summary of the 3-way RMANOVA procedures examining the treatment effects of nutrients additions $(N)$, presence of fish $(F)$, and depth of the water column (D) on the log transformed dependent variable heterotrophic flagellate abundance. ns: $p>0.130$

\begin{tabular}{|lccccc|}
\hline Source & SS & df & MS & Fratio & p value \\
\hline $\mathrm{N}$ & 16.50 & 1 & 16.50 & 154.39 & $<0.001$ \\
$\mathrm{~F}$ & 0.30 & 1 & 0.30 & 2.84 & $\mathrm{~ns}$ \\
$\mathrm{~N} \times \mathrm{F}$ & 0.21 & 1 & 0.21 & 1.96 & $\mathrm{~ns}$ \\
$\mathrm{D}$ & 0.004 & 1 & 0.004 & 0.04 & $\mathrm{~ns}$ \\
$\mathrm{~N} \times \mathrm{D}$ & 0.91 & 1 & 0.91 & 8.55 & 0.019 \\
$\mathrm{~F} \times \mathrm{D}$ & 0.04 & 1 & 0.04 & 0.38 & $\mathrm{~ns}$ \\
$\mathrm{~N} \times \mathrm{F} \times \mathrm{D}$ & 0.002 & 1 & 0.002 & 0.02 & $\mathrm{~ns}$ \\
Error & 0.11 & 8 & 0.10 & & \\
\hline
\end{tabular}

closures and lowest in the nutrient enriched enclosures. In the nutrient enriched enclosures (with or without fish) HNAN levels generally remained well below $2.0 \times$ $10^{3}$ cells $\mathrm{ml}^{-1}$. A sharp increase in HNAN abundance was observed in the nutrient enriched enclosures on the last sampling date, but HNAN levels still remained lower than what was found in the control and fish only enclosures.

Seasonal HNAN data for the deep enclosures indicated similar trends to what was observed in the shallow enclosures (Fig. 5B). HNAN abundance ranged

Table 7. Within-subject effects. Summary of the 3-way RMANOVA procedures examining the response of log transformed heterotrophic flagellate abundance to the addition of nutrients $(N)$, presence of fish $(F)$, and depth of the water column (D) during the sampling period. W: sampling week. A total of 6 sampling dates were included in the analyses

\begin{tabular}{|lrrr|}
\hline Source & df & Fratio & p value \\
\hline$W$ & 5 & 92.19 & $<0.001$ \\
$W \times N$ & 5 & 16.71 & 0.009 \\
$W \times F$ & 5 & 11.05 & 0.019 \\
$W \times N \times F$ & 5 & 17.17 & 0.008 \\
$W \times D$ & 5 & 41.58 & 0.002 \\
$W \times N \times D$ & 5 & 8.18 & 0.032 \\
$W \times F \times D$ & 5 & 36.18 & 0.002 \\
$W \times N \times F \times D$ & 5 & 45.44 & 0.001 \\
\hline
\end{tabular}


from 0.1 to $4.5 \times 10^{3}$ cells $\mathrm{ml}^{-1}$. Fish only and control enclosures followed very similar patterns, with HNAN increasing after the second sampling week (July 16) for the duration of the summer. The nutrient enriched enclosures, alone or in combination with fish, exhibited much lower HNAN than in the control and fish only enclosures. Fertilized enclosures maintained

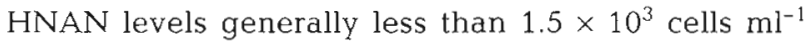
except in the $\mathrm{N}$ only enclosures, where there was a slight increase to $1.8 \times 10^{3}$ cells ml ${ }^{-1}$ in September.

Between-subject RMANOVA revealed that nutrient additions had a highly significant effect on HNAN ( $p$ $<0.001$ ) (Table 6). HNAN levels were reduced when nutrients were added (Fig. 6). HNAN were neither affected by the presence of fish ( $p>0.130)$ nor by the depth of the water column $(p=0.851)$. There was, however, a significant $\mathrm{N} \times \mathrm{D}$ interaction $(\mathrm{p}=$ 0.019 ). The nutrient effect observed was greater in the deep enclosures than in the shallow enclosures (Fig. 6). HNAN levels in the deep fertilized enclosures were considerably lower in comparison to the fertilized shallow.

Within-subject RMANOVA indicated that seasonal variation in HNAN abundance was due to all 3 treatment variables (Table 7). The HNAN response to the addition of nutrients $(p=0.009)$, presence of fish $(p=0.019)$, and depth of the water column $(p=0.002)$, including all the interaction effects of these treatment combinations, varied considerably during the 4 mo sampling period.

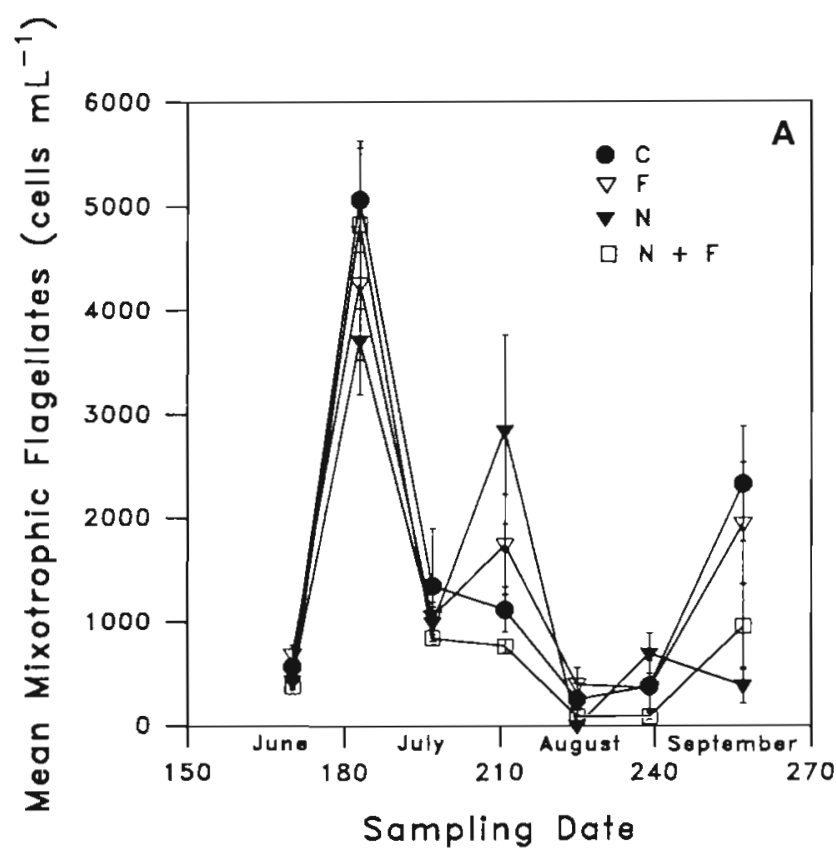

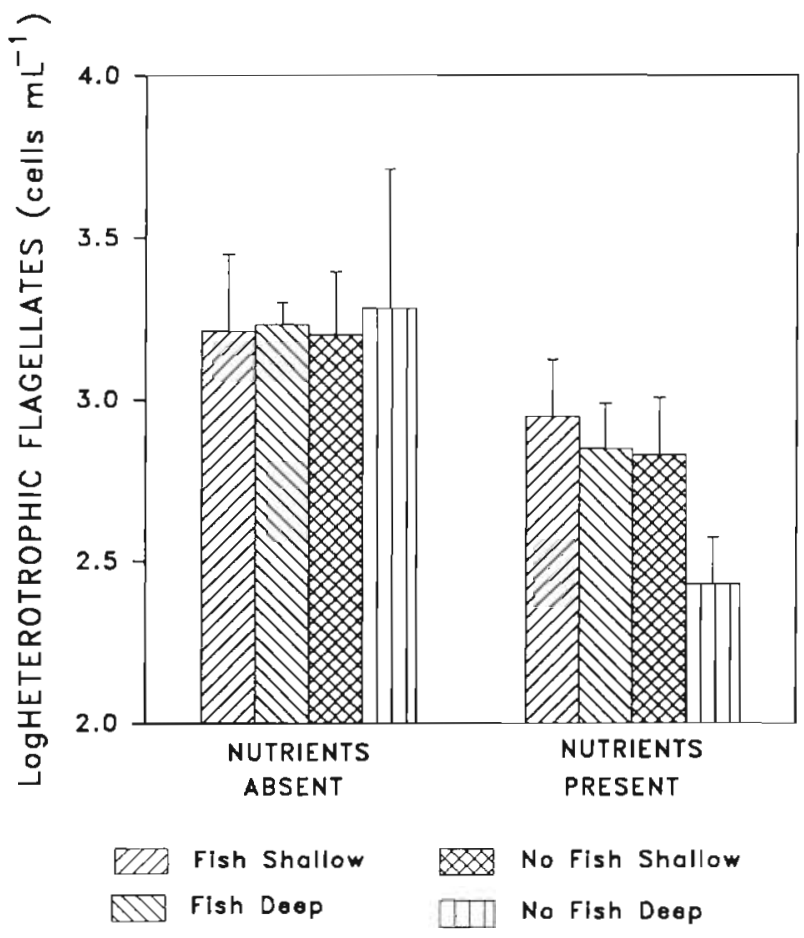

Fig. 6. Overall effects of the treatment variables on seasonal mean heterotrophic flagellate abundance. Treatments were: nutrient additions, presence of planktivorous fish and depth of the water column. Heterotrophic flagellate abundance has been $\log$ transformed. Six sampling dates were included in the analyses. Bars represent standard errors

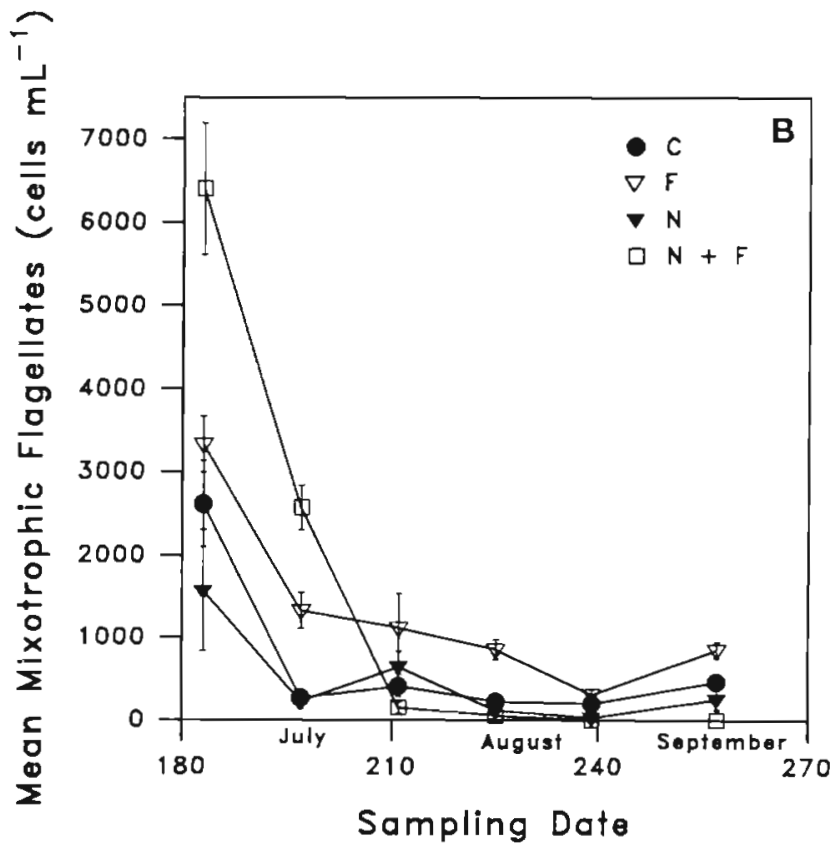

Fig. 7. Mean mixotrophic flagellate abundance in (A) the shallow enclosures $(3 \mathrm{~m})$ and $(\mathrm{B})$ the deep stratified enclosures (11 $\mathrm{m}$ ) during the sampling period June 19 to September 14, 1991. Error bars represent the standard deviation between replicate enclosures. Treatments were: $C$, control (no fish and no nutrient additions); F, planktivorous fish additions; $N$, nutrient additions; $\mathrm{N}+\mathrm{F}$, nutrient and fish additions. Numbers on the $\mathrm{x}$-axis represent Julian days 
Table 8. Between-subject effects. Summary of the 3-way RMANOVA procedure examining the treatment effects of nutrient additions $(N)$, presence of fish $(F)$, and depth of the water column (D) on the log transformed dependent variable mixotrophic flagellate abundance. ns: $p>0.071$

\begin{tabular}{|lccccc|}
\hline Source & SS & df & MS & Fratio & p value \\
& & & & & \\
$\mathrm{F}$ & 33.95 & 1 & 33.95 & 83.06 & $<0.001$ \\
$\mathrm{~N} \times \mathrm{F}$ & 0.009 & 1 & 0.009 & 0.02 & $\mathrm{~ns}$ \\
$\mathrm{D}$ & 5.58 & 1 & 5.58 & 13.65 & 0.006 \\
$\mathrm{~N} \times \mathrm{D}$ & 14.45 & 1 & 14.45 & 35.35 & $<0.001$ \\
$\mathrm{~F} \times \mathrm{D}$ & 1.65 & 1 & 1.65 & 4.04 & $\mathrm{~ns}$ \\
$\mathrm{~N} \times \mathrm{F} \times \mathrm{D}$ & 1.77 & 1 & 1.77 & 4.33 & $\mathrm{~ns}$ \\
Error & 11.91 & 1 & 11.91 & 29.15 & $<0.001$ \\
\hline
\end{tabular}

\section{Mixotrophic flagellates}

MiXO abundance in the shallow enclosures reached a maximum early in the sampling season but declined steadily throughout the remainder of the summer (Fig. 7A). The highest MIXO levels were observed in the control enclosures during early July $\left(5.1 \times 10^{3}\right.$ cells $\left.\mathrm{ml}^{-1}\right)$. MIXO levels in the fish only enclosures were generally lower and followed a similar pattern to what was observed in the control enclosures. The fertilized enclosures exhibited the

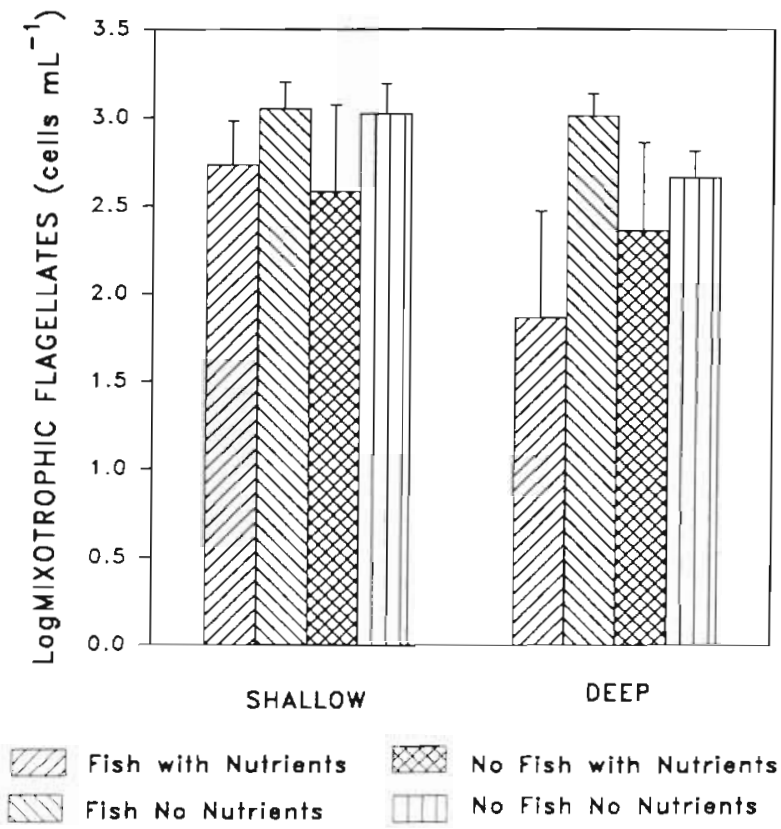

Fig. 8. Overall effects of the treatment variables on seasonal mean mixotrophic flagellate abundance. Treatments were: nutrient additions, presence of planktivorous fish and depth of the water column. Mixotrophic flagellate abundance has been $\log$ transformed. Six sampling dates were included in the analyses. Bars represent standard errors
Table 9. Within-subject effects. Summary of the 3-way RMANOVA examining the response of $\log$ transformed mixotrophic flagellate abundance to nutrient additions $(N)$. presence of fish $(F)$, and depth of the water column (D) during the sampling period. W: sampling week. A total of 6 sampling dates were included in the analyses

\begin{tabular}{|lrrr|}
\hline Source & df & Fratio & p value \\
\hline $\mathrm{W}$ & 5 & 67.98 & $<0.001$ \\
$\mathrm{~W} \times \mathrm{N}$ & 5 & 32.37 & 0.003 \\
$\mathrm{~W} \times \mathrm{F}$ & 5 & 50.18 & 0.001 \\
$\mathrm{~W} \times \mathrm{N} \times \mathrm{F}$ & 5 & 39.54 & 0.002 \\
$\mathrm{~W} \times \mathrm{D}$ & 5 & 87.79 & $<0.001$ \\
$\mathrm{~W} \times \mathrm{N} \times \mathrm{D}$ & 5 & 67.25 & $<0.001$ \\
$\mathrm{~W} \times \mathrm{F} \times \mathrm{D}$ & 5 & 12.34 & 0.015 \\
$\mathrm{~W} \times \mathrm{N} \times \mathrm{F} \times \mathrm{D}$ & 5 & 3.33 & 0.013 \\
\hline
\end{tabular}

lowest number of MIXO, usually less than $1.0 \times 10^{3}$ cells $\mathrm{ml}^{-1}$

In the deep enclosures, MIXO levels also peaked in early July $\left(6.4 \times 10^{3}\right.$ cells $\left.\mathrm{ml}^{-1}\right)$ in the $\mathrm{N}+\mathrm{F}$ treatment (Fig. 7B). However, MIXO numbers sharply declined to less than $0.01 \times 10^{3}$ cells $\mathrm{ml}^{-1}$ by early August and close to zero afterwards until the completion of the study. The MIXO levels in the control and nutrient enclosures also peaked in early July (between 1.5 and $2.5 \times 10^{3}$ cells $\mathrm{ml}^{-1}$ ) and remained below $0.4 \times 10^{3}$ cells $\mathrm{ml}^{-1}$ for the remainder of the season. The fish only enclosures exhibited a more gradual decline and supported higher MiXO levels at the end of the season in comparison to the other treatments.

MIXO levels were significantly lower in the fertilized enclosures ( $p<0.001$, Table 8, Fig. 8). There was also a significant depth effect $(p<0.001)$. MIXO levels were generally lower in the deep enclosures in comparison to the shallow. However, this depth effect was not clear in the MIXO seasonal trends. MIXO levels were not affected in a consistent manner by the presence of planktivorous fish. However, there was a significant $\mathrm{N} \times \mathrm{F}$ interaction effect $(p=0.006)$. Seasonal mean MIXO data indicate that the effect of nutrients was greater in the enclosures without fish (Fig. 8). Nutrient enclosures with no fish exhibited lower MIXO levels than enriched enclosures with fish. Seasonal variation of MIXO abundance depended on the addition of nutrients, presence of fish, and depth of the water column (Table 9). Seasonal changes were different in each treatment.

\section{DISCUSSION}

Of the 3 independent variables examined, nutrients clearly had the most significant effect on the abundance of all 4 components of the microbial food web. Although 
there were significant temporal changes in abundance in all the components, there was a strong overriding effect of the nutrient additions on the patterns observed. While nutrients significantly increased the abundance of HBAC, the other 3 components (PPICO, HNAN and MIXO) were, on average, negatively affected by nutrients. In the case of PPICO, this effect was predictable based on empirical studies across lake systems (Pick 1991). Similarly, because most of the MIXO were chrysophytes, the decline in their abundance with nutrient additions was also a predictable response based on empirical studies of chrysophyte distributions and experimental fertilization of lakes (see review by Sandgren 1988).

However, the significant decline in HNAN with the addition of nutrients was a surprising result given the positive correlations between HNAN and HBAC reported in the literature (Berninger et al. 1991) and the positive (albeit weak) correlation between HNAN and total phosphorus (Tzaras \& Pick 1994). In the fertilized enclosures, HNAN concentrations were always significantly lower than in the non-fertilized enclosures; the decline cannot be explained by a lack of prey because there was a significant increase in the fertilized enclosures of HBAC abundance as well as productivity (Table 1, Howard 1994). The increase in HBAC was likely triggered by the increases in algal biomass and primary production in the enriched enclosures (Table 1, Perin et al. 1996, Proulx et al. 1996). It would have been interesting to examine whether there were also size shifts in the bacterial community with the various treatments as observed for the algal community (Proulx et al. 1996).

In contrast to this study, Riemann (1985) found that nutrient additions had no significant effect on HNAN within smaller experimental enclosures for 2 dates in early summer for which data were provided. However, it should be noted that the lake he studied was highly eutrophic and nutrients may not have been limiting the system since HBAC biomass was not stimulated by nutrient additions. In the short-term (4 d) bag experiments of Pace \& Funke (1991) nutrient additions also led to no change in HNAN in one lake (Peter), but a significant increase was observed in the other lake studied (Paul). The 2 lakes in this study were not very different in their trophic status and the authors suggested that the differences were due to differences in predation pressure.

The presence of planktivorous fish alone $(+F)$ only had a significant effect on the abundance of PPICO. On average PPICO abundance was higher in the presence of fish. The exact mechanism behind this result cannot be determined but the presence of planktivorous fish may reduce loss rates via a reduction in herbivore grazing or nutrient supply rates may have been altered. In any case, the observation that the $\mathrm{N}+\mathrm{F}$ enclosures (particularly the shallow ones) maintained high PPICO may help to explain why some eutrophic lakes have high PPICO and others have insignificant populations (Stockner 1991). Christoffersen et al. (1993) also observed a summer increase in picoalgae (mainly cyanobacteria) in fish enclosures relative to fishless ones deployed in a shallow eutrophic lake.

Fish alone had no significant effect on HBAC, HNAN or MIXO abundance. This is in contrast to other enclosure studies, where the presence of planktivorous fish (and the associated removal of large daphnids) led to higher densities of HBAC and HNAN (e.g. Christoffersen et al. 1993, Markošová \& Jezek 1993). However, these studies have generally been conducted in eutrophic lakes.

In this study, although there was no main fish effect, there were some significant nutrient-fish interactions. HBAC abundance was highest under nutrient conditions in the presence of fish. There were no significant interactions with fish for HNAN but the decline in abundance with enrichment was most pronounced in the absence of fish in the deep enclosures. It would have been interesting to determine whether size shifts occurred in the HNAN community in addition to abundance. Since fish treatments generally tend to increase the importance of small cells (Vanni 1987, Mazumder et al. 1988, Prouix et al. 1996), a negative effect of fish on HNAN biomass might have been detected if there was an overall decrease in average size of HNAN.

The lack of a significant fish effect on HNAN abundance was not due to a lack of change at the level of the zooplankton community. In the enclosures containing planktivorous fish, the biomass and size distribution of zooplankton were significantly altered (Table 1, Proulx et al. 1996). This occurred principally by mid- to late summer since it took about $4 \mathrm{wk}$ following the removal of fish in the fishless enclosures for the large bodied cladoceran Daphnia middendorffiana to develop (Mazumder \& Lean 1994). Interestingly enough, such populations did not develop at all in the shallow fishless enclosures. In the enclosures containing fish, the zooplankton community was dominated by rotifers, small microzooplankton measuring between 41 and $200 \mu \mathrm{m}$. Increased rotifer abundance with the addition of planktivorous fish is consistent with other experimental studies (e.g. Mazumder et al. 1990, Lazzaro et al. 1992).

Many planktonic rotifers are relatively unselective, feeding on particles in the size range of 0.5 to $20 \mu \mathrm{m}$ (Rothhaupt 1990). Although this size range includes HNAN and HBAC as well as PPICO, the impact of rotifers is generally considered to be much less significant than that of large cladocerans (Arndt 1993). The increase in rotifers in the fish enclosures did not have a negative impact on HNAN. 
The lowest abundance of HNAN occurred in the deep nutrient enriched enclosures without fish. Although these enclosures contained Daphnia populations, cladoceran biomass was not much higher than in the control enclosures where HNAN populations were the highest (Table 1). This result is in contrast to several descriptive and experimental studies, which have indicated that populations of large Daphnia have negative impacts on HNAN. Jürgens (1992) found that the lowest HNAN numbers were found in German lakes where Daphnia species dominated the zooplankton. In the experiments of Riemann (1985), enclosures containing fish had elevated levels of HNAN presumably because of reduced predation from large Daphnia. In his fishless enclosures, zooplankton (particularly cladocerans) increased in abundance whereas HNAN abundance decreased and could not fully account for the bacterial turnover. Furthermore, Riemann (1985) concluded that in enclosures without fish, the cladocerans were effective grazers on bacteria. In the bag experiments of Pace \& Funke (1991), the cascading effect of Daphnia was usually stronger than the nutrient effect in determining final densities of HNAN. Interestingly, more recently, Pace et al. (1998) also found that HNAN did not increase in response to whole lake fertilization and that mortality from predation (but not necessarily due to Daphnia) accounted for the patterns observed.

In the present study, the underlying cause for the strong negative impact of nutrients on HNAN is not known. The results would support the general concept that the microbial loop is weaker in eutrophic conditions than in oligotrophic systems (Porter et al. 1988). Predation by Daphnia is not the explanation, but it is still possible that predation by other grazers not impacted by Daphnia was occurring. For example, ciliates are common in eutrophic water where bacterial densities are high and some species may graze on small HNAN and pico- and nanophytoplankton, thus providing another link to higher trophic levels. In mesotrophic to eutrophic lakes where bacterial densities are high, ciliates have been shown to play a key role in the energy transfer to higher trophic levels (e.g. Pace 1982, Weiss et al. 1990). Beaver \& Crisman (1982) found that ciliate concentrations varied from less than 10 to around 200 cells $\mathrm{mI}^{-1}$ in Florida lakes and that there was a significant correlation between ciliate numbers and chlorophyll $a$. If ciliates were responsible for the decline of HNAN in the enclosures, then one would expect ciliate abundance to increase with nutrient additions and not be affected by the presence of planktivorous fish. However, for the deep enclosures, abundance was highest in both the fish enclosures, followed by the control and was lowest in the enriched fishless treatment (Table 1, Marchessault \& Mazumder 1997).
Interestingly, the response of HNAN to the various treatments tracked more closely the response of PPICO than that of HBAC. PPICO can be an important food source for HNAN (Simek et al. 1997). Therefore it is possible that the HNAN growth rates were reduced in treatments where PPICO abundance was significantly lower, leading to lower HNAN abundance. HNAN abundance was most depressed in the enriched, fishless, deep enclosures where PPICO were also at their lowest concentrations. This hypothesis would require testing with direct grazing experiments that would estimate the relative importance of PPICO and $\mathrm{HBAC}$ to the growth of HNAN.

An alternative explanation for the decline in HNAN is that competition with phytoplankton for dissolved nutrients leads to declines in HNAN in the nutrient enclosures. Although HNAN are generally considered to obtain their mineral nutrients by feeding on bacteria, there is no evidence to suggest that they cannot also obtain dissolved inorganic nutrients across the cell membrane as do phytoplankton. It is possible that under the conditions of continuous nutrient additions larger algae simply outcompeted the HNAN for nutrients. Larger algae were stimulated by nutrient additions at least in the deep enclosures (Proulx et al. 1996).

There was also no effect of depth on HBAC and HNAN abundance while there was a depth effect on PPICO and MIXO. This depth effect was probably not due to any significant differences in nutrient concentrations since both the shallow and deep enclosures maintained similar nutrient levels in the epilimnion during the summer (Proulx et al. 1996). Originally, the enclosures were installed at 2 different depths to mimic stratified (deep) and continuously mixing (shallow) systems. When a deep lake stratifies, nutrient levels tend to decline in the surface waters and accumulate below the thermocline. In contrast, in shallow lakes, which continuously mix from top to bottom, nutrients get recirculated. An increase in $\mathrm{HBAC}$ and HNAN levels in the shallow enclosures relative to the deep enclosures was anticipated, presuming that the shallow enclosures would accumulate higher nutrient levels. However, Lac Croche has extremely nutrientpoor sediments which appeared to adsorb nutrients and the shallow enclosures did not accumulate more nutrients when compared to the deep enclosures.

In this study, heterotrophic flagellates and their principal food resource, heterotrophic bacteria, were not tightly coupled. Enclosures with increased nutrient levels supported higher bacterial levels but did not show a corresponding increase in heterotrophic flagellates. Heterotrophic nanoflagellate levels were significantly reduced with the addition of nutrients. The presence of planktivorous fish altered zooplank- 
ton community structure but did not significantly affect heterotrophic flagellate abundance. There was only significant evidence for cascading effects on picocyanobacteria populations.

Acknowledgements. This paper is dedicated to the memory of Marc Proulx, who had worked so tirelessly on the Lac Croche enclosures. We thank the rest of the crew (P. Marchessault, D. Quinn, and M. Trepanier) and the staff of the Station de biologie des Laurentides, St. Hyppolyte, Quebec, for providing outstanding working conditions. We thank the anonymous reviewers for their constructive comments. This work was funded by NSERC grants to F.R.P. and A.M. and through the support of the National Water Research Institute, Environment Canada, to D.R.S.L

\section{LITERATURE CITED}

Andersen P, Fenchel T (1985) Bacterivory by microheterotrophic flagellates in seawater samples. Limnol Oceanogr 30:198-202

Arndt H (1993) Rotifers as predators on components of the microbial web (bacteria, heterotrophic flagellates, ciliates)-review. Hydrobiologia 255/256:231-246

Azam F, Fenchel T, Field JG, Gray JS, Meyer-Reil LA, Thingstad $F$ (1983) The ecological role of water-column microbes in the sea. Mar Ecol Prog Ser 10:257-263

Beaver JR, Crisman TL (1982) The trophic response of ciliated protozoans in freshwater lakes. Limnol Oceanogr 27 : $246-253$

Bennett SJ, Sanders RW, Porter KG (1990) Heterotrophic, autotrophic and mixotrophic nanoflagellates: seasonal abundances and bacterivory in a eutrophic lake. Limnol Oceanogr 35:1821-1832

Berninger UG, Findlay BJ, Kuupo-Leinikki P (1991) Protozoan control of bacterial abundances in freshwater Limnol Oceanogr 36:147-159

Bird DF, Kalff J (1984) Empirical, relationships between bacterial abundance and chlorophyll concentration in fresh and marine waters. Can J Fish Aquat Sci 41:1015-1023

Christoffersen K, Rieman B, Klysner A, Sondergard M (1993) Potential role of fish predation and natural populations of zooplankton in structuring a plankton community in eutrophic lake water. Limnol Oceanogr 38:561-573

Cole JJ, Findlay S, Pace ML (1988) Bacterial production in fresh and saltwater ecosystems: a cross-system overview. Mar Ecol Prog Ser 43:1-10

Cushing DH (1989) A difference in structure between ecosystems in strongly stratified waters and in those that are only weakly stratified. J Plankton Res 11:1-13

Fahnenstiel G, Carrick HJ, Itturiaga R (1991) Physiological characteristics and food-web dynamics of Synechococcus in Lakes Huron and Michigan. Limnol Oceanogr 36: $219-234$

Fenchel T (1982) Ecology of heterotrophic microflagellates. IV. Quantitative occurrence and importance as bacterial consumers. Mar Ecol Prog Ser 9:35-42

Fenchel T (1987) Ecology of Protozoa: the biology of free-living phagotrophic protists. Springer-Verlag, New York

Gasol JM, Vaque D (1993) Lack of coupling between heterotrophic nanoflagellates and bacteria: a general phenomenon across aquatic systems? Limnol Oceanogr 38:657-665

Goldman JC, Caron DA (1985) Experimental studies on an omnivorous microflagellate: implications for grazing and nutrient regeneration in the marine microbial food chain. Deep-Sea Res 32:899-915

Gurevitch J, Chester ST Jr (1986) Analysis of repeated measures experiments. Ecology 67:251-255

Howard SM (1994) Influence of nutrients, planktivorous fish and stratification on aquatic microbial activity. MSc thesis, Trent University, Peterborough, ONT

Jürgens K (1994) Impact of Daphnia on planktonic microbial food webs-a review. Mar Microb Food Webs 8:295-324

Jürgens K, Güde H (1991) Seasonal changes in the grazing impact of phagotrophic flagellates on bacteria in Lake Constance Mar Microb Food Webs 5:27-37

Jürgens K, Wickham SA, Rothhaupt KO, Santer B (1996) Feeding rates of macro-and microzooplankton on heterotrophic nanoflagellates. Limnol Oceanogr 41:1833-1839

Kiørboe T, Kaas H, Kruse B, Møhlenberg F, Tiselius P, Artebjerg $G$ (1990) The structure of the pelagic food web in relation to water column structure in the Skagerrak. Mar Ecol Prog Ser 59:19-32

Lafond M. Pinel-Alloul P, Ross P (1990) Biomass and photosynthesis of size-fractionated phytoplankton in Canadian Shield lakes. Hydrobiologia 196:25-38

Lazzaro X, Drenner RW, Stein RA, Smith JD (1992) Planktivores and plankton dynamics: effects of fish biomass and planktivore type. Can J Fish Aquat Sci 49:1466-1473

Marchessault P, Mazumder A. (1997) Grazer and nutrient impacts on epilimnetic ciliate communities. Limnol Oceanogr 42:893-900

Markošová R, Ježek J (1993) Bacterioplankton interactions with Daphnia and algae in experimental enclosures. Hydrobiologia 264:85-99

Mazumder A, Lean DRS (1994) Consumer-dependent responses of lake ecosystems to nutrient loading. J Plankton Res 16:1567-1580

Mazumder A, McQueen DJ, Taylor WD, Lean DRS (1988) Effects of fertilization and planktivorous fish (yellow perch) predation on size distribution of particulate phosphorus and assimilated phosphate: large enclosure experiments. Limnol Oceanogr 33:421-430

Mazumder A, McQueen DJ, Taylor WD, Lean DRS, Dickman MD (1990) Micro- and mesozooplankton grazing on natural pico- and naoplankton in contrasting plankton communities produced by planktivore manipulation and fertilization. Arch Hydrobiol 118:257-282

MCQueen DJ, Post JR, Mills EL (1986) Cascading trophic interactions Uncoupling at the zooplankton-phytoplankton link. Hydrobiologia 159:277-296

Moss B, McGowan S, Carvalho L (1994) Determination of phytoplankton crops by top-down vs bottom-up mechanisms in a group of English lakes, the West Midland meres. Limnol Oceanogr 39:1020-1029

Nagata T (1988) The microflagellate-picoplankton food linkage in the water column of Lake Biwa. Limnol Oceanogr 33:504-517

Pace ML (1982) Planktonic ciliates: their distribution, abundance and relationship to microbial resources in a monomictic lake. Can J Fish Aquat Sci 39:1106-1116

Pace ML, Funke E (1991) Regulation of planktonic microbial communities by nutrients and herbivores. Ecology 72 : 904-914

Pace ML, Cole JJ, Carpenter SR (1998) Trophic cascades and compensation: differential responses of microzooplankton in whole-lake experiments. Ecology 79:138-152

Perin S, Pick FR, Lean DRS, Mazumder A (1996) Effects of planktivorous fish and nutrient additions on primary production of shallow versus deep (stratified) lake enclosures. Can J Fish Aquat. Sci 53:1125-1132 
Pick FR (1991) Picocyanobacteria abundance and composition in relation to light penetration. Limnol Oceanogr 36 : $1457-1462$

Pick FR, Agbeti M (1991) The seasonal dynamics and composition of photosynthetic picoplankton communities in temperate lakes in Ontario, Canada. Int Rev Ges Hydrobiol $76: 565-580$

Pick FR, Hamilton PB (1994) A comparison of seasonal and vertical patterns of phagotrophic flagellates in relation to bacterial and algal biomass in temperate lakes. Mar Microb Food Webs 8:201-216

Porter KG (1988) Phagotrophic phytoflagellates in microbial food webs. Hydrobiologia 159:89-97

Porter KG, Feig YS (1980) The use of DAPI for identification and enumeration of bacteria and blue-green algae. Limnol Oceanogr 25:943-948

Porter KG, Paerl H, Hodson R, Pace M, Priscu J, Riemann B, Scavia D, Stockner J (1988) Microbial interactions in lake food webs. In: Carpenter SR (ed) Complex interactions in lake communities. Springer-Verlag, New York, p 209-227

Proulx M, Pick FR, Mazumder A, Hamilton PA, Lean DRS (1996) Effects of nutrients and planktivorous fish on phytoplankton in shallow and deep systems. Ecology 77:1556-1572

Rassoulzadegan F, Sheldon RW (1986) Predator-prey interactions of nanozooplankton and bacteria in an oligotrophic marine environment. Limnol Oceanogr 31:1010-1021

Riemann B (1985) Potential importance of fish predation and zooplankton grazing on natural populations of freshwater bacteria. Appl Environ Microbiol 50:187-193

Rothhaupt KO (1990) Changes of the functional responses of the rotifers Brachionus rubens and Brachionus calyciflorus with particle sizes. Limnol Oceanogr 35:16-23

Saunders RW, Porter KG (1988) Phagotrophic phytoflagellates. In: Marshall KC (ed) Advances in microbial ecology. Plenum Press, New York, p 167-192

Sanders RW, Porter KG (1990) Bacterivorous flagellates as food resources for the freshwater crustacean zooplankter Daphnia ambigua. Limnol Oceanogr 35:188-191

Sanders RW, Porter KG, Bennett SJ. DeBiase AE (1989) Sea-

Editorial responsibility: Fereidoun Rassoulzadegan,

Villefranche-sur-Mer, France sonal patterns of bacterivory by flagellates, ciliates, rotifers and cladocerans in a freshwater planktonic community. Limnol Oceanogr 34:673-687

Sanders RW, Leeper DA, King CH, Porter KG (1994) Grazing by rotifers and crustacean zooplankton on nanoplanktonic protists. Hydrobiologia 288:167-181

Sandgren CD (1988) The ecology of chrysophyte flagellates: their growth, perennation strategies as freshwater phytoplankton. In: Sandgren CD (ed) Growth and reproductive strategies of freshwater phytoplankton. Cambridge University Press, Cambridge, p 9-104

SAS Institute Inc (1989) SAS user's guide: statistics, Ver 6.06.06. SAS Institute Inc, Cary, NC

Sherr EB, Sherr BF (1984) Role of heterotrophic protozoa in carbon and energy flow in aquatic ecosystems. In: Klug MJ, Reddy CA (eds) Current perspectives in microbial ecology. America Society for Microbiology, Washington, DC, p 412-423

Simek K, Hartman P, Nedoma J, Pernthaler J, Springmann D, Vrba J, Psenner R (1997) Community structure, picoplankton grazing and zooplankton control of heterotrophic nanoflagellates in a eutrophic reservoir during summer phytoplankton maximum. Aquat Microb Ecol 12:49-63

Stockner JG (1991) Autotrophic picoplankton in freshwater systems: the view from the summit. Int Rev Ges Hydrobiol $76: 483-492$

Tzaras A, Pick FR (1994) The relationship between bacterial and heterotrophic flagellate abundance in temperate lakes. Mar Microb Food Webs 8:347-355

Vanni MJ (1987) Effects of nutrients and zooplankton size on the structure of a phytoplankton community. Ecology 68: $624-635$

Vaqué D. Pace ML (1992) Grazing on bacteria by flagellates and cladocerans in lakes of contrasting food-web structure. J Plankton Res 14:307-321

Weisse T, Müller H, Pinto-Coelho RM, Schweizer A, Springmann D, Baldringer G (1990) Response of the microbial loop to the phytoplankton spring bloom in a large prealpine lake. Limnol Oceanogr 35:781-794

Submitted: May 29, 1998; Accepted: February 23, 1999

Proofs received from author(s): August 20,1999 